\title{
Urgent issues of estimation of problems and financial mechanisms of development of russian agrarian complex
}

\author{
Irina Oleynikova ${ }^{1, *}$, Tatyana Chernova $^{2}$, Tatyana Reshetilo $^{2}$ and Irina Yankina $^{2}$ \\ ${ }^{1}$ Taganrog Institute of Economics and Management, 45, Petrovskaya str., 347900, Taganrog, Russia \\ ${ }^{2}$ Polytechnic Institute the branch of FSBIE DSTU in Taganrog, 109-a, Petrovskaya str., 347900, \\ Taganrog, Russia
}

\begin{abstract}
The key problems of development of agrarian business were analyzed. Low dynamic potential of renewal of production process, lowering of employment in agricultural business, people abandoning rural localities, and inefficient system of agricultural pattern are mostly those problems. Authors established that among financial instruments intended to solve those problems are the system of budget program special purpose funding and bank credit products and they are the target to implement project decisions in the field of agribusiness. Agricultural credit cooperation will allow solving effectively the problems of small-scale agricultural industries and farming. The dynamics of the financial institutions within the specified field was analyzed and measures to activate the development of agricultural credit cooperation are advised.
\end{abstract}

\section{Introduction}

The significance in the system of worldwide economics as well as in national economics of various countries determines the pattern and the scales of institutional and financial mechanisms for functioning of agricultural business. Factors for data updating are the growth of population which tends to urbanize, distribution of standards of quality of living including preference in consumptions of foodstuffs, boosting of the level of technology of agricultural production, the growth of international competitiveness on the markets of agricultural raw materials and supplies. These issues several times have been the subjects for scientific research of Russian and foreign surveys.

The World Bank's reports [1,2] says that despite the advance in agricultural production and trade balance Russia continues to lag behind many comparator countries in measures of crop and livestock productivity. The main risks are intensification of stress in training amidst global economic slowdown and inducing further economic sanctions.

V. Frumkin in his researches describes economic effects of sanctions that were induced towards Russian manufacturers and responsive countersanctions on Russian agroindustrial complex which build the escalation on the market of food supplies. The conclusion that it is

\footnotetext{
*Corresponding author: i.oleynikova@tmei.ru
} 
necessary to increase the support from the government and to improve the work of institutions which develop the agro-industrial complex is done [3].

Professor V. Uzun [4, 5] analyzed the most important institutional and structural changes in agriculture of Russia and revealed that expansion of agricultural holdings has drawn to decrease of employment in agriculture and decreasing of rural population. Particular qualities of the Russian policy of support of agriculture are explained and it is proved that Russia's entering the WTO showed unification of quality protection of Russian producers and consumers of agricultural products.

V. Kortchenya's researches [6] estimate the process of agricultural performance of Russia according to data envelopment analysis and the big technology gap in comparison to advanced economies that tends to decline is noticed.

Thus, the research emphasizes the identification of issues in the development of agricultural business, the general positive and negative impact of the government support measures on the growth of agricultural production and the level of rural employment. However, one of the main factors in the success of the institutional and regulatory conditions for agricultural business is a stable financing involved in activities on all stages of production, and this determined the purpose and milestones of this study.

\section{Materials and Methods}

In the scope of mentioned above a system approach to the analysis of the problems of the development of the nowadays agro-industrial complex of Russia and justification for the use of a set of financial mechanisms focused on project financing of technical and technological renewal of agricultural production and the development of rural territories applied as the methodological basis of the study. And most attention is drawn to development of the practice of agricultural credit cooperation. In the course of the study the program-oriented and goal-oriented approach to reveal priorities of the subject and methods of institutional analysis and system approach are applied. And statistical analysis of macroeconomic performances of agricultural development in the period of 2009-2019 was carried out. Program-methodological documents that regulate the ways and measures of State support of the agricultural sector were examined. The features of special purpose funding of agro-industrial complex from the federal budget is analyzed.

\section{Results}

The agro-industrial complex is one of the backbone types of economic activity in the national economy of Russia. Its functional significance is predetermined by the following circumstances [7]:

- formation of a raw material base for the food processing industry;

- food security;

- increase of economic development of territories;

- stimulation of growth rates and diversification of national export potential;

- increasing of internal and external competitiveness of the national economy;

- stimulation of employment growth, including through both a large industrialized agricultural business and small forms of agricultural production and processing of agricultural products.

Although the arguments mentioned above, one cannot say that the growth rate of the agro-industrial complex, and in particular its core agriculture is sustainable (Fig. 1). The calculation of indicators is based on data collected by the Federal State Statistics Service on 
the dynamics of GDP at current prices [8] and agricultural products [9]. The figure represents the values of agricultural production growth rates.

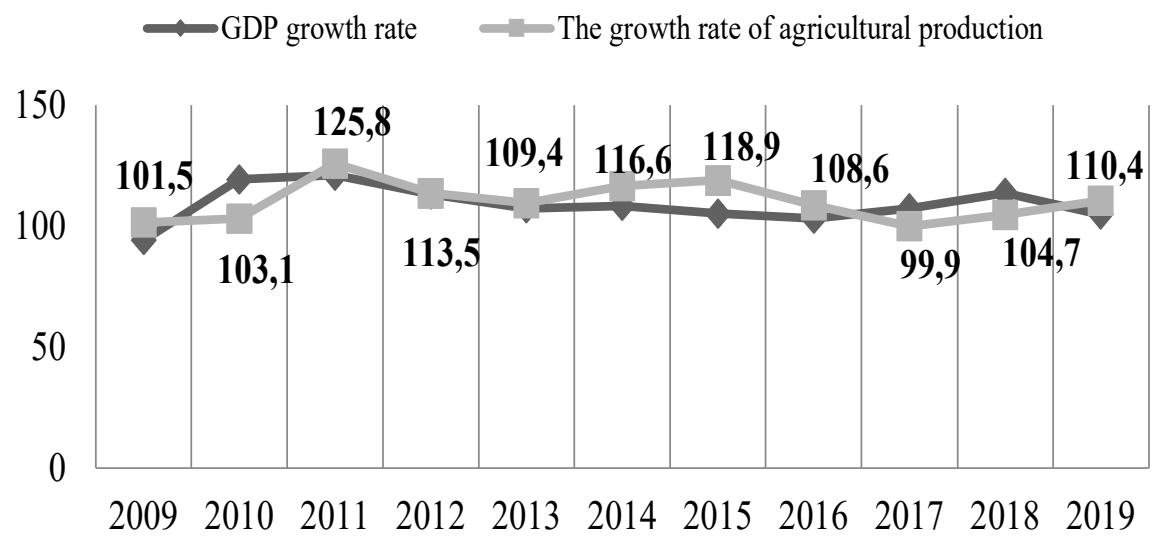

Fig. 1. Growth rates of agricultural production in comparison with GDP growth rates, $\%$.

In the reporting period, the growth rate of agricultural production is positive except 2017 when the growth rate was next to none. A pronounced contribution to this dynamics was made by the price component. To illustrate this thesis, we present the indices of agricultural production in comparable prices [9] in Fig. 2. The shown dynamics reflects insufficient rates of development of agricultural production.

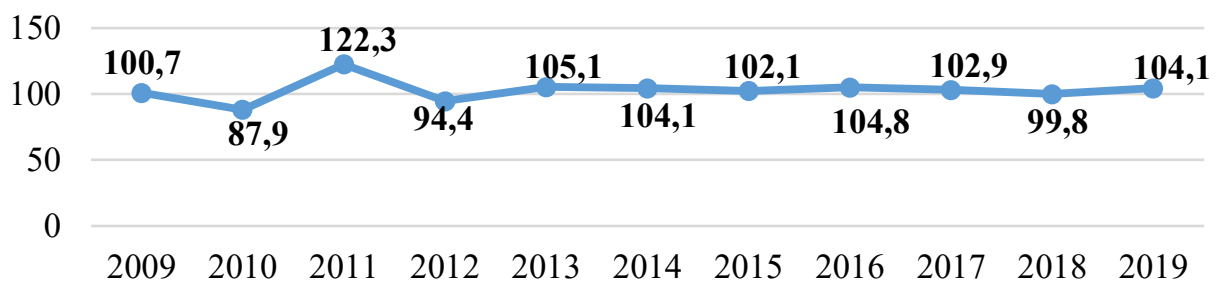

Fig. 2. Indices of agricultural production by category of farms in the Russian Federation in comparable prices, $\%$.

Hereunder we specify the key problems that restrict the development of the agricultural sector in the Russian economy.

The first one is insufficient level of technological equipment of enterprises of the agroindustrial complex. Depreciation of fixed assets amounted to $38.2 \%$ in 2018 [10], which is slightly lower than the average for the country's economy (46.6\%), but one should take into account the specifics of agricultural production it requires modern means of mechanization that increase the level of labor productivity and this is a fairly significant indicator. This problem becomes particularly significant in the context of the sustainable introduction of a new technological paradigm focused on the introduction of innovative technical and technological foundations for the introduction of agricultural business. The components of the new technological paradigm in the field of agricultural production in Fig. 3 are shown. 


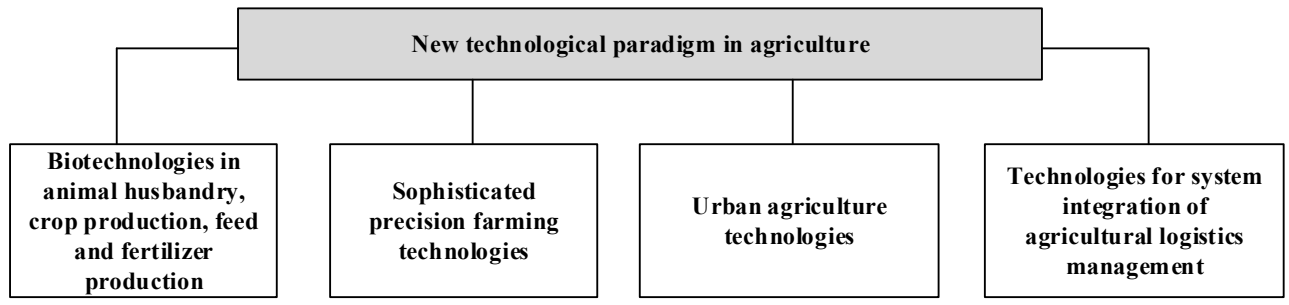

Fig. 3. Main components of the new technological paradigm of agriculture.

The second key problem is a decrease in agricultural employment due to the low level of social development of rural areas and a significant population reduction of the rural localities. Since the 1990s the rural population has been steadily decreasing population a significant part of population is employed in non-core areas of activity and is diverted to the informal employment sector. According to the labor force survey conducted by the Federal State Statistics Service [11] the rural population in 2018 was $25.5 \%$ of the total population of Russia and it is 37.4 million people, $47.1 \%$ or 17.6 million people among them are employable, however 16.3 million people among them are employed and 1.3 million people are unemployed. The structure of labor force employment of the rural population is described in Fig. 4 (compiled by the authors based on [11].

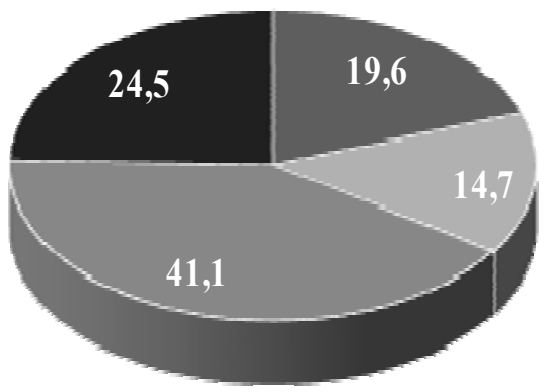

- Agriculture " Wholesale " Budget sphere - Other activities

Fig. 4. The structure of labor force employment in the rural population, \%.

Informal employment of the rural population is quite significant. It is 5 million people or $28.4 \%$ of the labor force concentrated within the borders of rural localities and more than $40 \%$ of informally employed people carry out activities in the field of agriculture. The rural depopulation and reducing employment in the agricultural sector has become significant and is characterized by researchers as depopulation of rural localities due to a number of negative factors: the low level of development of transport system, social and engineering infrastructure, limited availability of governmental and municipal services (the, so to say, Digitalization cannot fully solve the problem of access to these services, as more than 4 million people lives in settlements where there is no access to the Internet, and just about $60 \%$ of rural households have broadband Internet access [12]), limited access (however it varies from region to region) to high-quality public services (many rural localities have no up to date water and gas supply services). Rural labor is also unattractive, primarily it is because average monthly wages it is normally and mostly constantly less than $60 \%$ of the average Russian salary.

The third group of key problems by the insufficient level of business process management, the lack of effective logistics mechanisms in the field of consumer marketing of manufactured products and access to the market, lacking of planning technologies for the management of production and sales of agricultural products that does not allow optimizing 
the number of intermediaries during its promotion, and reducing barriers to interaction between consumers and producers is determined. The unresolved problem is the promotion of agricultural products for export. This brings to significant limitations in improving the efficiency of agricultural production. It is advisable to include in the system of indicators characterizing the effectiveness of the organization of business processes and the general level of management in the agricultural sector: the level of marketability of products, the share of gross value added in the total cost of manufactured products, the level of profitability of agricultural activity.

Fig. 4 shows the level of marketable value of certain types of agricultural products according to activities (based on [13]).

The low value of indicators of marketability of products in certain categories depends on the low level of processing, the lack of up to date infrastructure for storage and arranging raw materials for sale that are a significant reserve for increasing the profitability and cost effectiveness of agricultural enterprises. Nowadays, over $90 \%$ of primary agricultural products are sold to third-party processing and wholesale enterprises and there are not too many farms that organized at least primary processing of their production, and this does not allow to most agricultural producers to participate heavily in the creation and redistribution of value added.

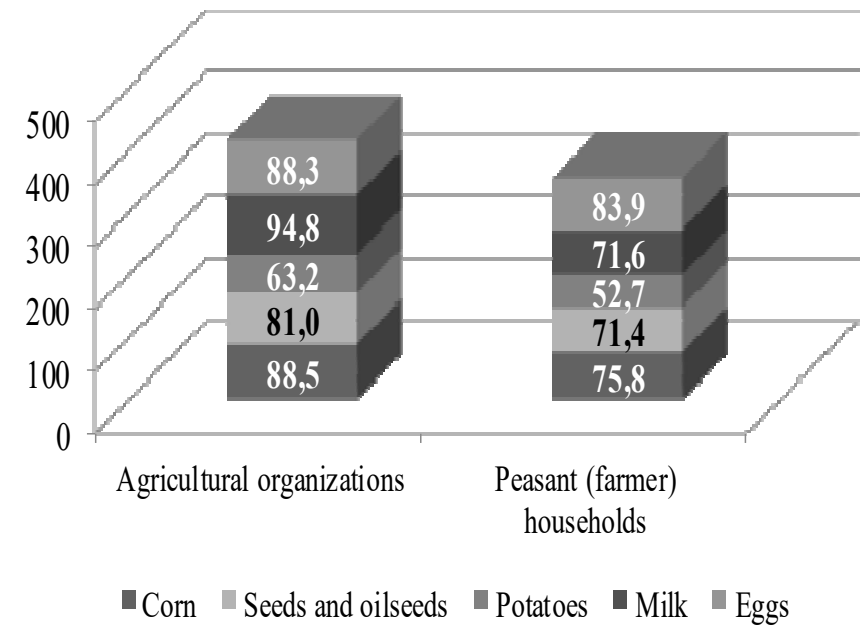

Fig. 5. The level of marketability of certain types of agricultural products by type of farm, $\%$.

The share of gross value added in gross agricultural output according to current prices in Fig. 6 (based on [12]) is shown. The presented data indirectly confirm the nonequivalence of the relationship between sectors of the economy and the withdrawal of agricultural value added to other areas [14].

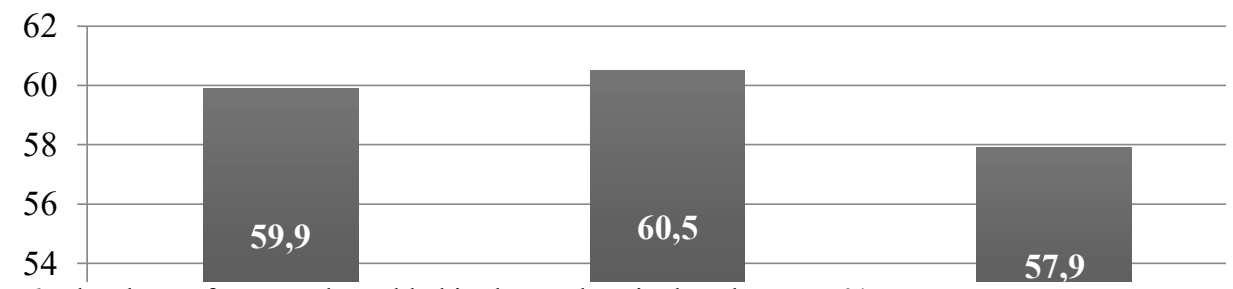

Fig. 6. The share of gross value added in the total agricultural output, $\%$. 
The insufficient level of added value and negative growth rates limit the profitability of the agricultural business. So in 2018 the profitability ratio of sold agricultural products was $15.4 \%$ and the share of unprofitable enterprises reached $26.9 \%$.

The solution to the above problems can be achieved through the development of financial mechanisms that combine government support measures based on the methodology of targeted state budgeting and market mechanisms for commercial debt financing.

Budgetary mechanisms for financial support of the agricultural sector within the hierarchy of state and municipal targeted programs are implemented. Primary tools of internal state support of agriculture within the framework of the state program "Development of agriculture and regulation of agricultural products, raw materials and food markets for 2013-2020" were formed and they take into account development priorities.

The program is focused on the integrated development of all sectors, sub-sectors, and fields of activity of the agro-industrial complex keeping in mind restrictions on state support measures because of Russia's membership in the WTO, as well as participation in the Eurasian Economic Union and other regional alliances in the CIS economic space [12]. Because of tasks that intend to deeply develop objectives of the industry under circumstances of sanctions and counter-sanctions measures taken in 2014-2015 funding of the program has been extended. As a result the total amount of financial support on this program is 8212.2 billion rubles, of which the federal budget allocations make up $43.1 \%$ of the sum from federal budget, the budget allocations from the consolidated budgets of the regions give $5.9 \%$, and extrabudgetary sources infuse $51.0 \%$ of the above specified sum. In 2018 approaches to implement of the state program have been modified and this allowed allocating the project and process parts of the program (Table 1, build on [14]). The total amount of budget financing of the state program in 2018 was:

Table 1. The volume and project and process structure of financing from the federal budget of the state program intended to development of agriculture in 2018.

\begin{tabular}{|l|c|c|}
\hline \multicolumn{1}{|c|}{ Name of programme document } & $\begin{array}{c}\text { Amount of } \\
\text { financing. } \\
\text { million rubles }\end{array}$ & $\begin{array}{c}\text { Share in total } \\
\text { funding \% }\end{array}$ \\
\hline $\begin{array}{l}\text { State program for the development of agriculture and } \\
\text { regulation of agricultural products. raw materials and food } \\
\text { markets for 2013 - 2020 }\end{array}$ & 219483.8 & 100 \\
\hline \multicolumn{2}{|c|}{ Project part of the program - 78.5\% } & 29.2 \\
\hline $\begin{array}{l}\text { Departmental project "Development of agricultural sectors } \\
\text { providing accelerated import substitution of the main types } \\
\text { of agricultural products. raw materials and food" }\end{array}$ & 64095.4 & 42.4 \\
\hline $\begin{array}{l}\text { Departmental project "Promotion of investment activity in } \\
\text { the agricultural sector" }\end{array}$ & 93045.1 & 6.4 \\
\hline $\begin{array}{l}\text { Departmental project "Technical modernization of the } \\
\text { agricultural sector" }\end{array}$ & 13999.9 & 0.5 \\
\hline Priority project "Export of agricultural products" & 1131.2 & 8.8 \\
\hline \multicolumn{2}{|c|}{ The process part of the program- 21.5\% } \\
\hline $\begin{array}{l}\text { Subprogram "Management to implement the state } \\
\text { program" }\end{array}$ & 19412.4 & 7.1 \\
\hline $\begin{array}{l}\text { Subprogram "Ensuring the general conditions of the agro- } \\
\text { industrial complex sectors functioning " }\end{array}$ & 15490.2 & 5.1 \\
\hline $\begin{array}{l}\text { Subprogram "Development of melioration of agricultural } \\
\text { lands of Russia" }\end{array}$ & 11207.1 & 0.1 \\
\hline $\begin{array}{l}\text { Subprogram "Researches of the development of } \\
\text { agricultural sectors" }\end{array}$ & 225.9 & 0.4 \\
\hline Subprogram "Sustainable rural localities development" & 876.6 & \\
\hline
\end{tabular}


The data in the table confirm the priority of the project approach in the development of the agricultural sector as the share of the project part of the program was $78.5 \%$. The financial instruments of the program are:

- grants to provide decoupled support to agricultural producers (consolidated subsidies and inter-budget transfers). Those grants are provided for co-financing of expenditure obligations of the constituent entities of the Russian Federation implementing regional and municipal programs aimed at supporting agriculture;

- targeted subsidies to agricultural producers, for example intended to increase productivity in dairy cattle breeding; to help achieving the targets of regional agribusiness development programs; to reimburse a part of the interest rate on investment debt instruments in the agro-industrial complex; to reimburse lost income and reimbursement of actually incurred costs in connection with the production or sale of goods (when selling equipment at prices that are lower than market ones) to agricultural machinery manufacturers; to compensate a part of the cost of transporting agricultural and food products;

- additional capitalization in the form of contributions to the authorized capital of Rosagroleasing JSC to develop affordable agricultural machinery leasing and to build the business chain "production-storage-transportation-processing-marketing" of products. This additional capitalization combined with the implementation of the company's development strategy until 2024 should ensure the sum of the leasing portfolio of about 97 billion rubles [15];

- conducting procurement and commodity interventions on agricultural markets;

- budget investments in the construction of industrial, civilian facilities, housing, and infrastructure;

- grants in the form of subsidies to implement integrated scientific and technical projects in the agricultural sector.

Despite the importance of financial measures of state support to the agricultural sector the results of their impact cannot be considered unambiguous since they are focused primarily on large agribusiness enterprises and do not create incentives for cost savings and efficient spending of funds. As well as not focused on involving financial and credit services of a wide range by credit institutions (except Rosagroleasing JSC, Rosselkhozbank JSC, the Russian state corporation for the development of VEB.RF) to support farmers.

Agricultural lending remains an unattractive area for the banking business this is confirmed by the share of loans provided in this segment in the sectoral structure of corporate lending (Fig. 7, based on [16]).

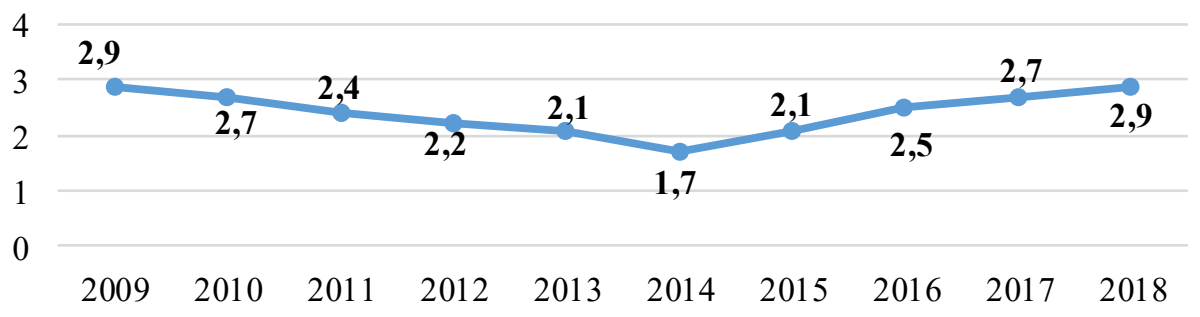

Fig. 7. The share of loans provided to the agricultural sector from the total volume of loans granted to legal entities both residents and individual entrepreneurs, $\%$.

These insignificant rates of agricultural lending appear due to the current banking regulation and supervision standards based on strict requirements according to the level of banking risks. It is possible to count on the future growth of such lending exclusively in the 
context of the development of project financing mechanisms in the field of technical modernization of the agro-industrial complex and the development of rural localities.

The way out of this situation is the development of non-banking support segment i.e. agricultural consumer credit cooperation. Small-scale agricultural producers, small agribusiness, peasant farms need affordable credit resources, but commercial banks satisfy the demand of these economic entities only on $10 \%$. Nowadays the Ministry of Agriculture of the Russian Federation has approved methodological recommendations to work out subprograms for the development of agricultural cooperation in the constituent entities of the Russian Federation that are intended to support small-scale farming. However, due the attention to the mechanisms of functioning of credit cooperation in the countryside is not sufficient, although the data from the financial market statistics demonstrate a significant institutional contraction of this segment (Fig. 8 based on [17]).

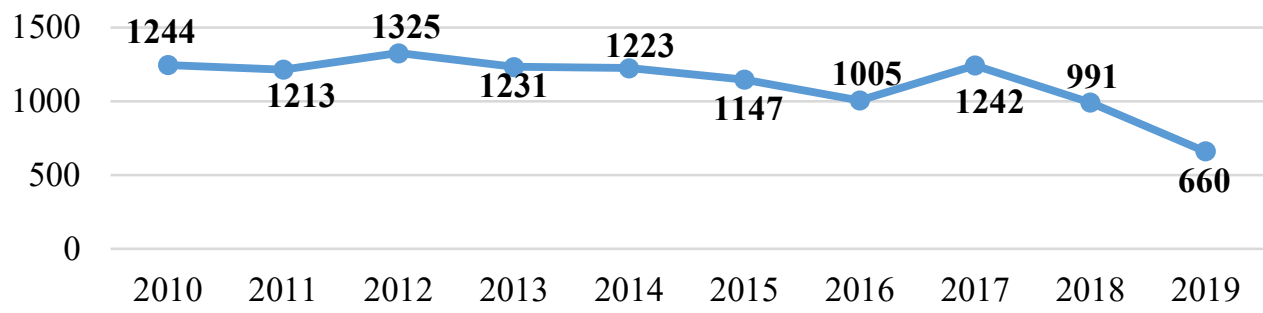

Fig. 8. Dynamics of the number of agricultural credit consumer cooperatives, units.

The specifics of agricultural credit consumer cooperatives and their significance in the development of the agricultural sector is as follows:

- focused on meeting the needs of the rural population who are members of these organizations. The activities of cooperatives have a social orientation, contributing to an increase in the overall well-being of rural areas;

- contribute to the development of small enterprises and peasant farms, create the prerequisites for attracting financial resources, and reduce the turnover of shadow borrowed capital;

- less susceptible to credit and liquidity risks, those risks are typical for banking institutions, as they unite citizens living in a certain territory, carry out a limited list of financial transactions and therefore are protected from market fluctuations in the financial market;

- possess informational advantages in interacting with their clients most of which are geographically tied to a specific rural locality.

The reduction of the total number of agricultural credit consumer cooperatives depends on rather stringent supervisory standards of the Bank of. Differences in the range of activity of individual cooperatives necessitate the use of a differentiated approach to implement regulatory measures (proportional regulation). It is advisable to create a vertically integrated model of agricultural credit cooperation. The core of this model should be regional and interregional self-regulatory organizations which combine and regulate the activities of cooperatives operating in rural settlements. Within the framework of this model a system of financial support and ensuring of the financial sustainability of agricultural credit consumer cooperation should be implemented.

\section{Discussion}

The carried out analysis made it possible to substantiate the importance of decentralized financial mechanisms for the functioning of the agricultural sector. In world practice the 
key institutions for the development of these mechanisms is agricultural consumer credit cooperation but its development in Russia is in its infancy and financial market statistics show a steady decline in the number of credit cooperatives operating in rural settlements.

Below follows the proposals to develop agricultural credit consumer cooperation:

- accommodate the development of agricultural credit consumer cooperation in the priority lines of the state agrarian policy and consider it as an element of the financial structure to support small business and farming;

- improve the regulatory model of agricultural credit consumer cooperatives by transferring these functions to specialized self-regulatory organizations on the regional and interregional levels as well as the creation of a specialized regulatory unit under the auspices of the Ministry of Agriculture that supervises the activities of self-regulatory organizations;

-develop a set of specialized measures for the financial protection of the rights of owners and investors of agricultural credit consumer cooperatives and to provide legal special procedures for the bankruptcy of individuals i.e. borrowers of these cooperatives;

- provide a set of tax benefits that reduce the tax burden on agricultural credit consumer cooperatives.

\section{References}

1. Russia: Policies for Agri-Food Sector Competitiveness and Investment in 2017. International Bank for Reconstruction and Development. The World Bank, www.worldbank.org

2. Increasing the role of internal reforms on the background of the decreasing forecast of the world economy. Report on the Russian economy. The World Bank, www.worldbank.org

3. B. Frumkin, Voprosy Ekonomiki 12, 147-153 (2015) doi.org/10.32609/0042-87362015-12-147-153

4. V. Uzun, N. Shagaida, Voprosy Ekonomiki 4, $39-58$ (2019) doi.org/10.32609/00428736-2019-4-39-58

5. V. Uzun, Voprosy Ekonomiki 10, 132-149 (2012) doi.org/10.32609/0042-8736-201210-132-149

6. V. Korotchenya, Voprosy Ekonomiki 4, 144-155 (2016) doi.org/10.32609/0042-87362016-4-144-155

7. H. El Bilali, Journal of Cleaner Production 1, 353-364 doi.org/10.1016/j.jclepro.2019.02.232.

8. Gross domestic product annual data. Federal State Statistics Service, https://www.gks.ru/accounts

9. Agricultural products. Federal State Statistics Service, https://gks.ru/free_doc/new_site/business/sx/tab-sel1.htm

10. The degree of depreciation of fixed assets in the Russian Federation to the end of the year according to a type of economic activity. Federal State Statistics Service, https://gks.ru/free_doc/new_site/business/osnfond/STIZN_ved.htm

11. Labor force survey 2018. Federal State Statistics Service, https://www.gks.ru/folder/11110/document/13265

12. Final report of the Ministry of Agriculture of the Russian Federation on the results of activities for http://mcx.ru/upload/iblock/10c/10c6695082afd0ac0ea4b6e41 fa3f6d9.pdf

2018 , 
13. Agriculture in Russia. 2019, https://www.gks.ru/storage/mediabank/sh_2019.pdf

14. Report on Federal budget performance in 2018. Russian Federal Treasury, https://roskazna.ru/ispolnenie-byudzhetov/federalnyj-byudzhet/

15. Strategy of development of JSC "Rosagroleasing" up to 2024, https://www.rosagroleasing.ru/company/

16. The volume of loans granted to resident legal entities and individual entrepreneurs in rubles according to a type of economic activity and specific areas of use of funds. Bank of Russia, https://cbr.ru/statistics/

17. Microfinance, https://cbr.ru/finmarket/supervision/sv_micro/ 